\title{
Perancangan Animasi 3D Gedung Fakultas Teknik Universitas Serambi Mekkah Sebagai Media Informasi
}

\author{
Baihaqi $^{1 *}$, Maulinda, Maghfiratul Ulfa ${ }^{3}$ \\ 1,2 Staf Pengajar Program Studi Teknik Informatika \\ ${ }^{3}$ Mahasiswa Program Studi Teknik Informatika \\ Fakultas Teknik Universitas Serambi Mekkah \\ Jl. T. Imum Lueng Bata Batoh - Banda Aceh
}

*Koresponden email: baihaqi@ serambimekkah.ac.id

\begin{abstract}
Abstraks : Dalam rangka untuk mensosialisaikan dan menginformasikan fakultas teknik yang terdapat di Universitas Serambi Mekkah perlu adanya suatu media yang dapat digunakan sebagai sarana informasi. Media tersebut berupa Animasi 3D untuk menarik minat calon mahasiswa yang ingin masuk ke perguruan tinggi. Oleh sebab itulah peneliti ingin membuat sebuah media animasi 3D menggunakan software Blender 2.79. Animasi tersebut berisi media grafis yaitu berupa gambar, arsitektur gedung, property, tulisan dan audio. Software Adobe Premiere Pro digunakan untuk proses editing audio. Adapun tujuan penelitian ini adalah sebagai media promosi kepada seluruh lapisan masyarakat, khususnya masyarakat di Provinsi Aceh dalam bentuk suatu tampilan animasi interaktif yang bertemakan tentang profil Fakultas Teknik Universitas Serambi Mekkah. Penelitian ini menghasilkan sebuah media animasi yang mudah dipahami serta bermanfaat dalam rangka mempromosikan fasilitas-fasilitas yang terdapat di fakultas teknik Universitas Serambi Mekkah kepada calon mahasiswa baru. Untuk mengetahui kelayakan media animasi 3D ini digunakan uji kuesioner terhadap 20 responden. Hasil uji kuesioner ini memiliki nilai rata-rata sebesar $85 \%$ responden yang setuju dengan kelayakan media animasi 3D ini. Sehingga dapat disimpulkan bahwa media animasi 3D yang telah berhasil diproduksi dapat digunakan oleh Fakultas Teknik Universitas Serambi Mekkah sebagai media informasi dan promosi.
\end{abstract}

Kata Kunci : Animasi 3D, Profil Fakultas Teknik, Aplikasi Blender 2.79, Adobe Premiere Pro, Kuesioner.

Abstract. In order to socialize and inform the engineering faculty at Serambi Mekkah University, needs a media that can be used as a means of information. The media is in the form of 3D animation to attract the interest of prospective students who want to enter college. Therefore, researchers want to create a 3D animation media using Blender 2.79 software. The animation contains graphic media in the form of images, building architecture, property, writing and audio. Adobe Premiere Pro software is used for audio editing. The purpose of this study is as a media campaign for all levels of society, especially the people in Aceh Province in the form of a display of interactive animation themed about the profile the Faculty of Engineering, Serambi Mekkah University. This research produced an animated media that was easy to understand and useful in order to promote the facilities contained in the engineering faculty of the Serambi Mekkah University for prospective new students. To find out the feasibility of 3D animation media, a questionnaire test was used on 20 respondents. The results of this questionnaire test have an average value of $85 \%$ of respondents who agree with the feasibility of this $3 \mathrm{D}$ animation media. So it can be concluded that 3D animation media that have been successfully produced can be used by the Faculty of Engineering, Serambi Mekkah University as a medium of information and promotion.

Keywords: 3D Animation, Profile of the Faculty of Engineering, Application Blender 2.79, Adobe Premiere Pro, Questionnaire.

\section{Pendahuluan}

Universitas Serambi Mekkah adalah sebuah perguruan tinggi swasta yang terdapat di Provinsi Aceh, terdiri dari berbagai Fakultas yang tunduk dibawah civitas akademikanya. Salah satunya yaitu Fakultas Teknik yang terdiri dari empat program studi yaitu Program Studi Teknik Industri, Teknik Lingkungan, Teknik Kimia dan Teknik Informatika. Yayasan Pembangunan Serambi Mekkah (YPSM) didirikan pada tanggal 21 Maret 1984 oleh salah seorang pendiri negara Republik Indonesia (Pahlawan Nasional RI) yaitu DR. Mr. Haji Teuku Moehammad Hasan (Alm) yang tertuang dalam akta Notaris nomor 76 tahun 1984.
Seiring dengan berjalannya waktu perkembangan kampus Universitas Serambi Mekkah khususnya di Fakultas Teknik sebagai salah satu perguruan tinggi yang menghasilkan sumber daya manusia, kini telah meningkatkan jumlah dan mutu serta sarana dan prasarana pendidikan sesuai dengan kebutuhan perkembangan ilmu pengetahuan dan teknologi. Perkembangan kemajuan yang telah dilakukan oleh Fakultas Teknik Universitas Serambi Mekkah, dapat menjadi informasi yang berguna bagi seluruh lapisan masyarakat, khususnya masyarakat Aceh dalam memilih perguruan tinggi yang ada di Provinsi Aceh. Media informasi yang disajikan dalam mempromosikan dan menginformasikan perkembangan Fakultas Teknik 
Universitas Serambi Mekkah dewasa ini hanya menggunakan media brosur, video dan media website.

Penggunaan media informasi tersebut dalam mempromosikan dan menginformasikan perkembangan kampus Fakultas Teknik Universitas Serambi Mekkah, khususnya mengenai fasilitas sarana dan prasarana kampus belum sepenuhnya dapat diinformasikan secara efektif. Media Animasi diperlukan sebagai tambahan dan pendukung dalam mempublikasikan dan menginformasikan perkembangan kampus di Lingkungan Fakultas Teknik Universitas Serambi Mekkah untuk seluruh lapisan masyarakat.

Proses pembuatan animasi profil Prodi di lingkungan Fakultas Teknik Universitas Serambi Mekkah ini dilakukan dengan menggunakan Software Blender. Software Blender bisa digunakan untuk modeling, texuring, lighting, animasi dan video post processing 3 dimensi. Aplikasi Blender juga merupakan sebuah software pengolah 3 dimensi dan animasi yang bisa dijalankan di Windows, Machintos, dan Linux. Satu lagi kelebihan blender yang diinginkan banyak orang dan ditakuti oleh software 3D komersial lainnya adalah software ini sepenuhnya gratis sehingga biaya produksi dapat lebih dipangkas.

Pembuatan animasi profil ini dapat menjadi sebuah solusi untuk mengenalkan kepada dunia luar mengenai gambaran umum profil Prodi di lingkungan Fakultas Teknik Universitas Serambi Mekkah, khususnya tentang pelayanan dan fasilitas sarana dan prasarana pendidikan yang diberikan. Dengan memanfaatkan teknologi media animasi komputer, yaitu animasi kampus profile yang berbasis multimedia interaktif, diharapkan dapat menjadi media informasi unggulan dan dapat memudahkan masyarakat dalam memperoleh berbagai informasi perkembangan fasilitas sarana dan prasarana yang paling urgensi yang ada di lingkungan kampus Universitas Serambi Mekkah.

\section{Tinjauan Pustaka}

Peta virtual 3D ini diajukan untuk memberikann fasilitas bagi masyarakat awam untuk mengenal jurusan teknik informatika di ITS baik dari segi bangunan maupun simulasi berbagai proses bisnis yang ada didalamnya[3]. Dengan adanya peta virtual 3D ini masyarakat dapat mengenal jurusan Teknik Informatika ITS dengan baik tanpa harus mengunjungi secara fisik dan memiliki kebebasan akses kedalamnya tanpa terkait dari waktu.

Belum ada media informasi mengenai gedung bersejarah di kota Surabaya dan belum semua remaja kota Surabaya mengetahui sejarah gedung, arsitekturnya, dan letak lokasi dari gedung bersejarah peninggalan Belanda tersebut[4]. Melihat perkembangan teknologi saat ini media aplikasi mobile dapat menjadi salah satu media yang sesuai dengan kebutuhan remaja kota Surabaya untuk mempermudah mendapatkan informasi mengenai gedung bersejarah penggunan aplikasi mobile dapat menyebar dengan mudah namun dibutuhkan untuk mempromosikan aplikasi tersebut supaya sampai kepada target audience yaitu dengan melalui media pendukung dapat menarik perhatian target audience untuk mengetahui informasi mengenai gedung bersejarah peninggalan Belanda di kota Surabaya ini.

Model gedung fakultas teknik yang biasanya hanya berbentuk gambar dibuat model berupa 3D dalam bentuk animasi[6]. Produksi film animasi gedung Fakultas Teknik Universitas Sam Ratulangi dengan perspektif animasi 3D ini menggunakan teknik tracking kamera. Tracking camera merupakan cara untuk melihat dari model 3D yang terbuat dengan pandangan camera yang berjalan sendiri. Pemodelan gedung berdasarkan gambar gedung hasil observasi yang dibuat menjadi model 3D. hasil akhir dari pembuatan film animasi 3D dari gedung Fakultas Teknik Unsrat dalam bentuk animasi 3D yang dapat membantu user atau mahasiswa untuk lebih mengetahui daerah gedung Fakultas Teknik Unsrat ini. Selain itu melalui pembuatan film animasi 3D dari model gedung ini juga diharapkan dapat digunakan sebagai modul presentasi untuk memperkenalkan gedung Fakultas Teknik Unsrat kepada pihak lain.

Animasi juga merupakan suatu teknik menampilkan gambar berurut sedemikian rupa sehingga penonton dapat merasakan adanya ilustrasi gerakan pada gambar yang ditampilkan[2]. Definisi tersebut mengartikan bahwa benda - benda mati dapat hidup. Animasi dipandang sebagai suatu hasil proses dimana obyek - obyek yang digambarkan atau divisualisasikan tampak hidup[8]. Kehidupan tersebut dapat dinyatakan dari suatu proses pergerakan. Meskipun demikian, animasi tidak dinyatakan pada obyek - obyek mati yang kemudian digerakkan. Benda - benda mati, gambaran - gambaran, bentuk yang digerakkan memang dapat dikatakan sebagai suatu bentuk animasi, akan tetapi esensi dari animasi tidak sebatas pada unsur menggerakkan itu sendiri, jika kehidupan memang diidentikkan dengan pergerakan, maka kehidupan itu sendiri juga mempunyai karakter kehidupan.

Animasi ada beberapa jenis[7], diantaranya adalah :

1. Animasi 2D (2 dimensi)

Animasi 2D biasa juga disebut dengan film kartun. Kartun sendiri berasal dari kata cartoon, yang artinya gambar yang lucu.

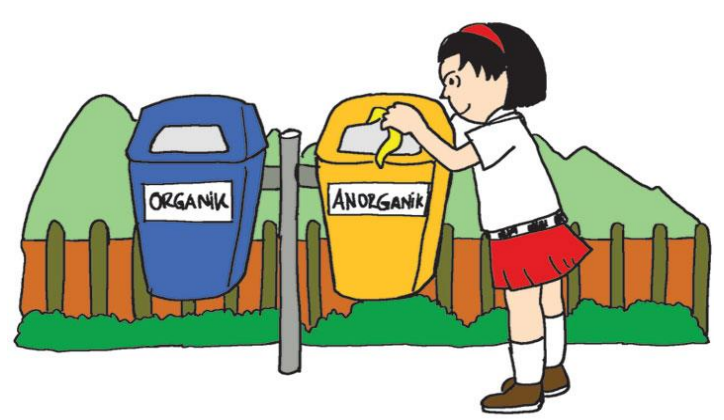

Gambar 1. Contoh animasi 2D

\section{Animasi 3D (3 dimensi) / karakter}

Perkembangan teknologi dan komputer membuat teknik pembuatan animasi 3D semakin berkembang dan maju pesat. Animasi 3D adalah pengembangan dari animasi 2D. Dengan animasi 3D, karakter yang diperlihatkan semakin hidup dan nyata, mendekati wujud aslinya[9]. 


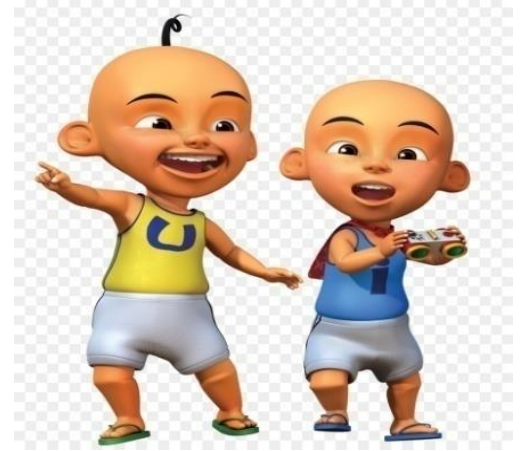

Gambar 2. Contoh animasi 3D

\section{Animasi Tanah liat (Clay Animation)}

Animasi ini memakai plasticin, bahan lentur seperti permen karet yang ditemukan pada tahun 1897.Tokoh-tokoh dalam animasi Clay dibuat dengan memakai rangka khusus untuk kerangka tubuhnya. Animasi Clay termasuk salah satu jenis dari Stop-motion picture. Film Animasi Clay pertama dirilis bulan Februari 1908 berjudul A Sculptors Welsh Rarebit Nigtmare.

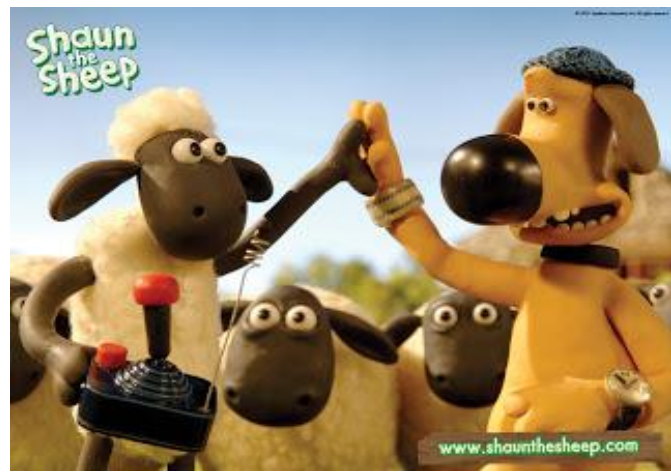

Gambar 3. Contoh animasi tanah liat (clay)

\section{Animasi Sel}

Animasi sel merupakan lembaran-lembaran yang membentuk animasi tunggal[10]. Contohnya: Tom and Jerry, Mickey Mouse dan detektif conan.

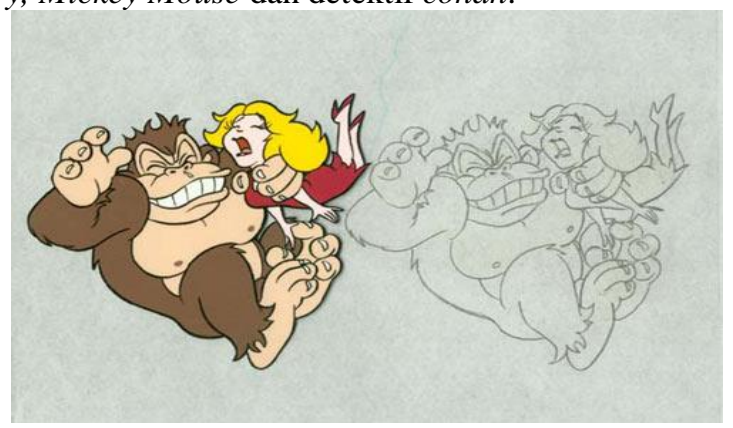

Gambar 4. Contoh animasi sel

Animasi 3D adalah animasi yang berwujud tiga dimensi meskipun bukan dalam bentuk 3D yang sebenarnya, yaitu bukan fisiknya, namun dalam wujud 3D dalam layar kaca 2D (layar tv, bioskop, komputer, proyektor, dan media sejenisnya)[1]. Tidak seperti animasi 2D yang memiliki dimensi panjang $(\mathrm{X})$ dan lebar $(\mathrm{Y})$, animasi 3D selain memiliki ke 2D tersbut juga memiliki dimensi kedalaman (Z).

Animasi 2D bersifat datar (flat), sedangkan animasi 3D memiliki kedalaman (volume) bentuk. Animasi 3D dapat di definisikan sebagai animasi yang dapat di lihat dari berbagai sudut pandang (poinof view). Tahapan animasi 3D secara keseluruhan di kerjakan dengan media komputer, mulai dari tahap modeling, texturing, lighting, sampai rendering. Keunggulan utama dari animasi 3D adalah fisualisasi objek yang tampak lebih nyata dan mendekati bentuk aslinya. Keunggulan lain adalah kemampuanya untuk membuat dan mewujudkan fisualisasi dengan yang sulit dan tidak mungkin atau bahkan yang nampak mustahil.
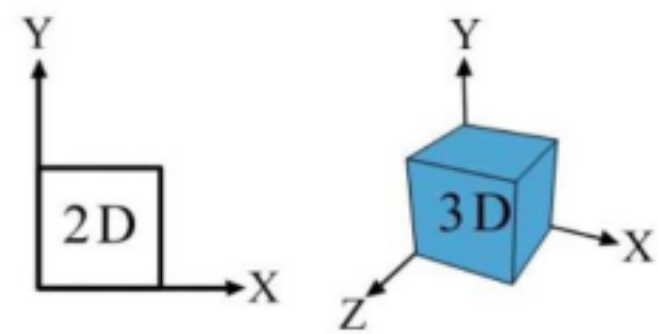

Gambar 5. Titik antar sudut 2D dan 3D

Blender adalah sebuah software pemodelan animasi 3D yang memilik fitur game engine, blender pada awalnya dikembangkan oleh perusahaan animasi Belanda Neogeo sebagai program animasi internal[5], blender tumbuh dan berkembang bersama proyek yang dikerjakan NeoGeo. Kemudian tidak lama setelah versi gratis di publis di internet, NeoGeo tidak lagi menjalankan bisnisnya. Pada saat itu Ton Roosendaal, bapak dari blender dan programmer utama, membuat perusahaan yang bernama NOT a number untu mengembangkan blender lebih jauh. Blender bias menjadi sebuah produk, versi gratis dari blender bukanlah versi demo namun berfungsi penuh, dan lisensinya memungkinkan penggunaan tak terbatas untuk produk komersial.

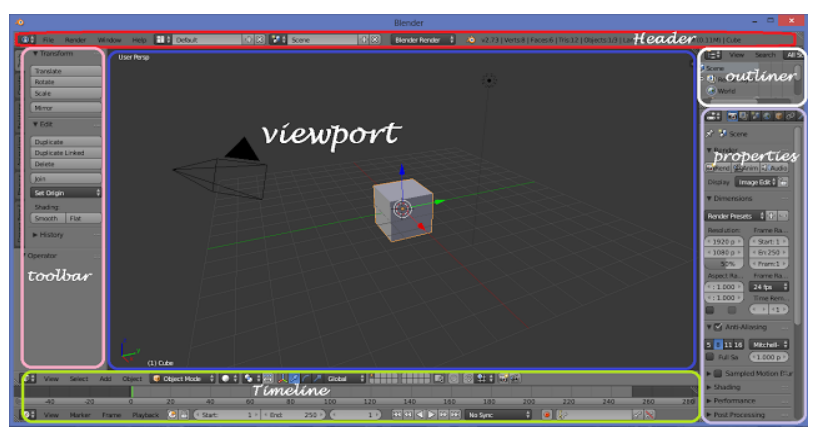

Gambar 6. Tampilan Bagian-bagian pada Blender

1. Header : Menu utama blender yang terdiri atas file, add, render, dan help

2. Viewport : Tampilan yang terdiri dari objek $3 \mathrm{D}$ atas objek lainnya. 
3. Toolbar : Terdiri atas daftar tools yang memiliki sifat dinamis menurut objeknya.

4. Outliner : Struktur data dari objek pada blender.

5. Properties : Panel yang memuat berbagai macam perintah untuk memodifikasi objek atau animasi dan bersifat dinamis mengikuti objek atau tools yang sedang aktif.

6. Timeline : Instruksi yang terkait dengan frame animasi atau squencer.

\section{Metodologi Penelitian}

Dalam menyelesaikan penelitian ini diperlukan beberapa aspek penunjang di antaranya rancangan flowchart seperti yang terlihat pada gambar di bawah ini.

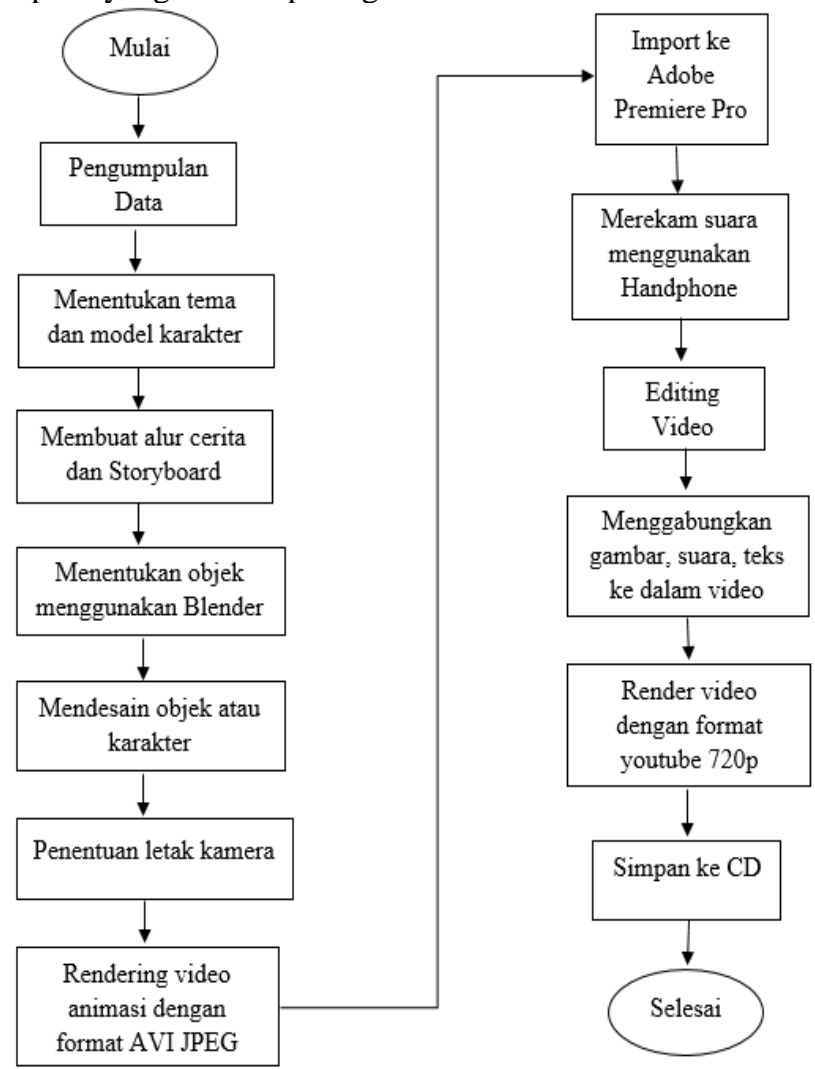

Gambar 7. Rancangan Flowchart

\section{Proses Pra Produksi}

Merupakan tahap yang harus ditempuh sebelum memasuki proses produksi. Fungsi dari tahap ini adalah sebagai landasan utama dalam pembuatan film dimana jenis cerita, penokohan, alur cerita, dan pembentukan karakter film ditentukan ditahap ini.

1. Analisis Piranti

2. Ide Cerita

3. Sinopsis

4. Desain

5. Skenario

6. Storyboard

\section{Tahap Produksi}

Merupakan tahap dimana proses pembuatan film tersebut dimulai. Inti dari pembutan film adalah pada tahap produksi.
Dalam tahap ini terjadi beberapa pekerjaan yang dilakukan secara estafet dan teratur.

1. Dubbing

2. Music dan sound effect

\section{Tahap Pasca Produksi}

Merupakan tahap akhir dalam pembuatan film animasi yaitu berupa process rendering dan convert video.

\section{Rendering}

Render secara istilah dapat diartikan suatu langkah akhir transformasi citra atau scane tiga dimensi untuk menghasilkan suatu citra baru yang dapat ditampilkan dilayar.

2. Convert Video

Merupakan tahap merubah format film yang berekstensi .AVI ke format video standar, seperti .mpeg. Di dalam storyboard ini kita dapat melihat sketsa gambar yang disusun berurutan sesuai dengan naskah, pada storyboard ini terdapat 33 scene yang dimulai dengan tampilan scene 01 yaitu cover pembuka dan diakhiri dengan scene 33 yaitu cover animasi penutup, sehingga menghasilkan persepsi yang sama pada cerita.

\section{4.' Hasil dan Pembahasan}

Hasil dari animasi profil prodi dilingkungan fakultas teknik yaitu terdiri dari beberapa penggabungan scene menjadi sebuah animasi pendek yang berisikan penyampaian informasi adalah sebagai berikut:

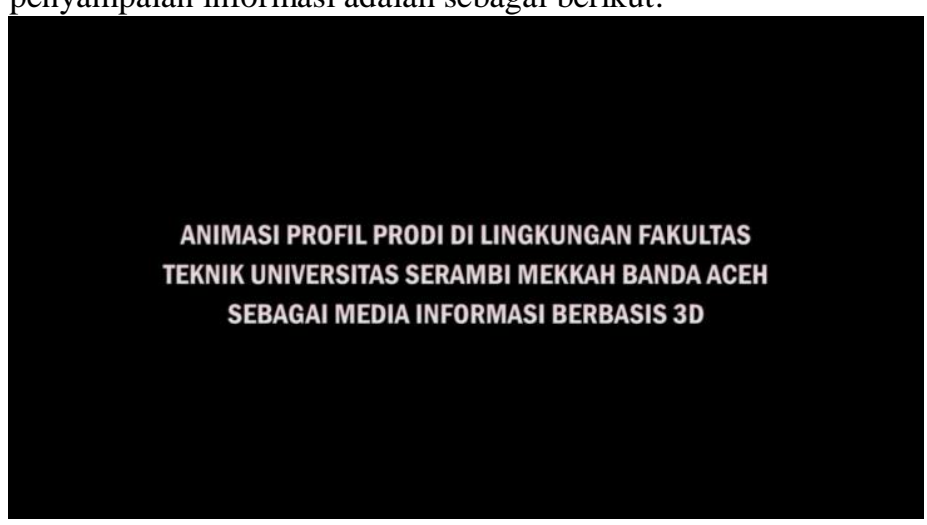

Gambar 8. Scene pertama

Pada scene kedua dalam gambar 9 ini menampilkan logo sebagai hasil karya dari mahasiswa Universitas Serambi Mekkah

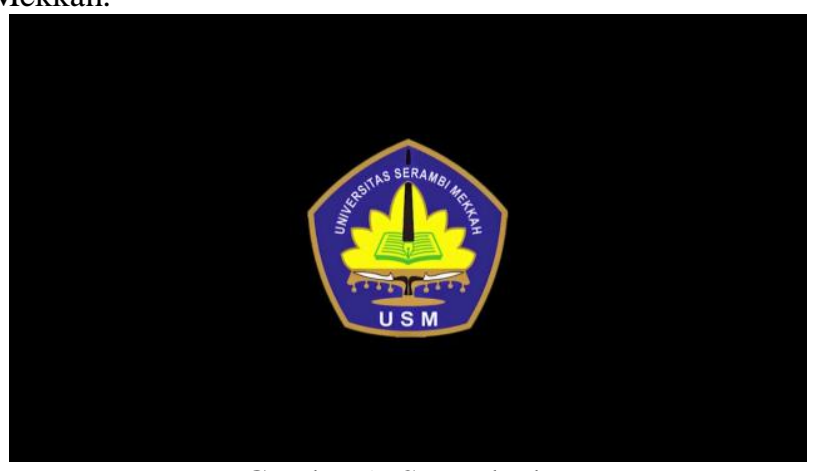

Gambar 9. Scene kedua 
Tampilan opening ini mengunakan Logo Universitas Serambi Mekkah yang diedit menggunakan software Adobe Premiere Pro dan dibarengi musik latar belakang.

Pada scene keempat gambar 10 menampilkan seluruh halaman Fakultas Teknik. Tampilannya mulai dari tampak halaman depan, samping, belakang dan sekeliling gedung.

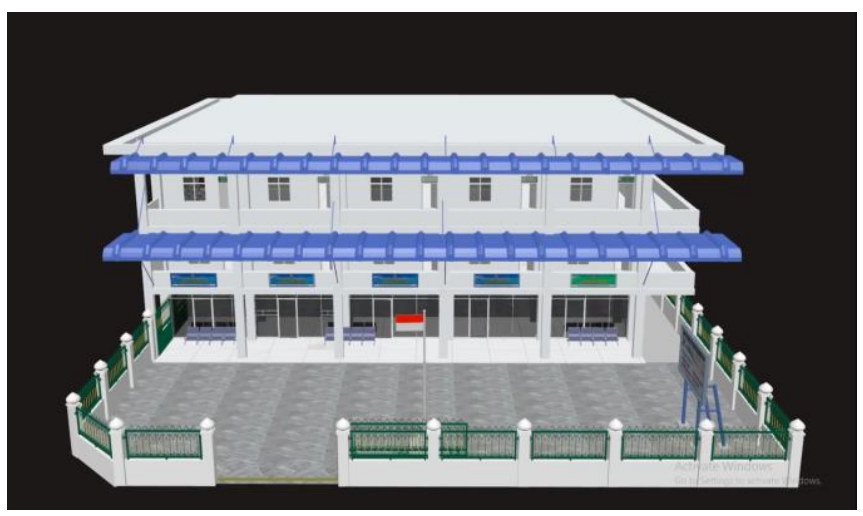

Gambar 10. Scene keempat

Pada tahap ini untuk meletakkan posisi kamera dengan cara mengaktifkan kamera terlebih dahulu dengan cara klik numpad 0 , lalu atur posisi > shortcut i > pilih location $>$ atur timeline ke detik $12>$. Kemudian atur kembali posisi kamera yang ingin dipindahkan lalu pilih location. Sedangkan untuk isi dubbing menggunakan adobe premiere pro yang dilengkapi dengan backsound aransement lembut sehingga video animasinya lebih menarik untuk dilihat.

Pada scene kelima gambar 11 menampilkan logo serta teks baliho dari Fakultas Teknik sebagai identitas kampus.

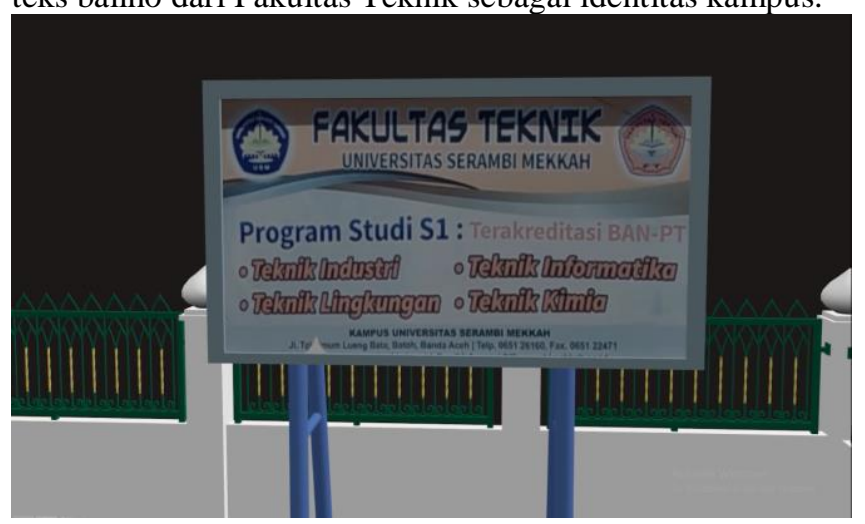

Gambar 11. Scene kelima

Pada scene keenam gambar 12 menampilkan ruangan akademik secara menyeluruh dan semua property yang ada di akademik.

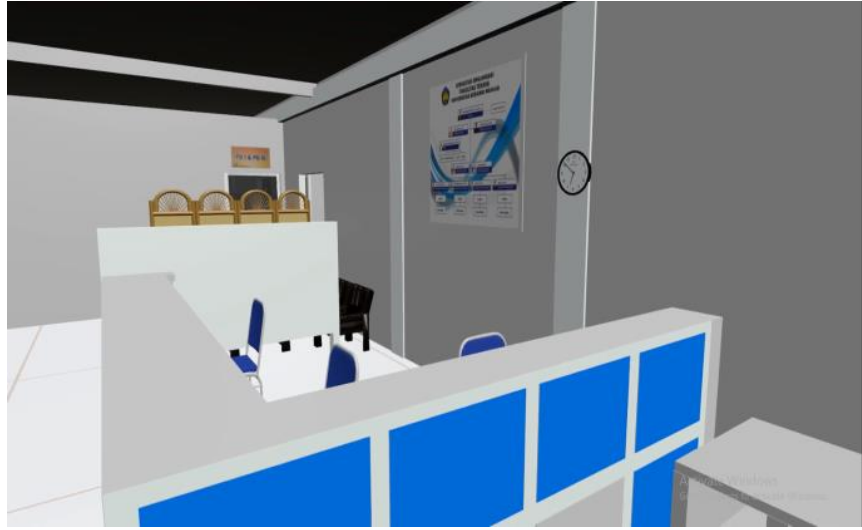

Gambar 12. Scene keenam

Pada pengambilan kamera ruang ini disorot dari sudut depan sampai belakang. Pembuatan meja akademik disini dibuat menggunakan object cube melalui proses edit mode yang di estrude.

Pada scene ketujuh gambar 13 menampilkan seluruh property yang ada di ruang Dekan Fakultas Teknik Universitas Serambi Mekkah.

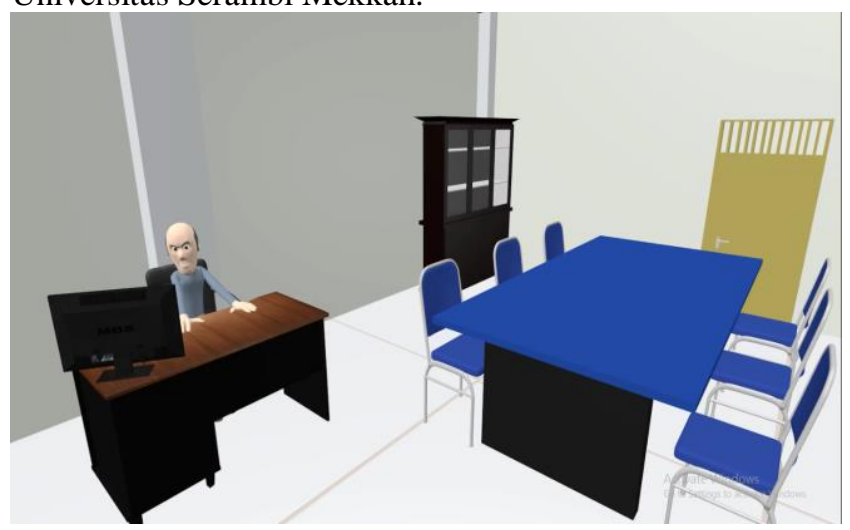

Gambar 13. Scene ketujuh

Pada ruang ini ditambahkan dengan sebuah karakter yang berperan sebagai Dekan Fakultas Teknik. Untuk pergerakan karakter disini dengan cara menggeser gerakan yang diinginkan lalu atur timingnya sesuai durasi video yang berjalan kemudian locrot.

Pada scene kesepuluh gambar 14 menampilkan ruangan dosen Fakultas Teknik secara menyeluruh mulai dari meja staf hingga meja dosen.

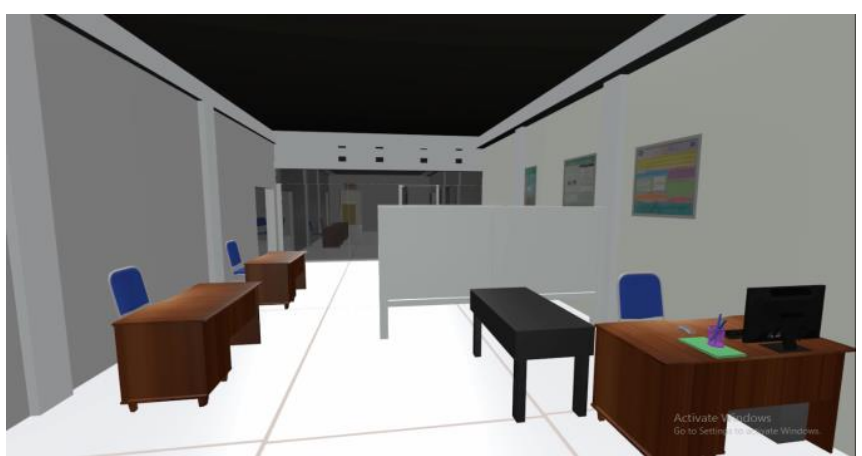

Gambar 14. Scene kesepuluh 
Pembatas masing-masing meja dosen dibuat menggunakan object plane, dan poster yang ada di setiap dinding dibuat dengan cara mengextrude foto kedalam wall.kemudian untuk property seperti computer di ambil dengan cara append.

Pada scene kesebelas gambar 15 menampilkan ruang arsip Fakultas Teknik. masing-masing property yang ada seperti computer diambil menggunakan append.

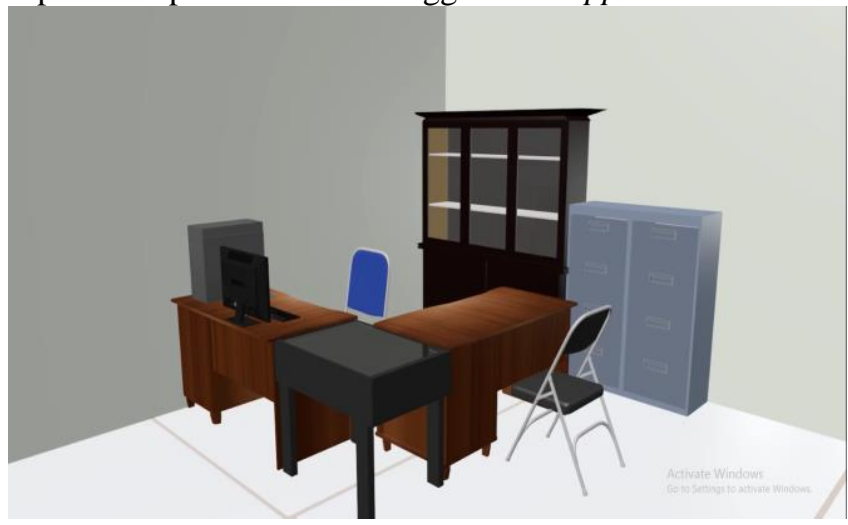

Gambar 15. Scene kesebelas

Pada lemari arsip dibuat dengan cara klik add lalu pilih object cube dan masuk ke edit mode untuk di estrude sesuai model gambar. Kemudian untuk memperlihatkan ruangan secara menyeluruh gunakan pencahayaan dan atur kamera yang sesuai.

Pada scene ketigabelas gambar 16 menampilkan ruang perpustakaan Fakultas Teknik. Buku yang ada di perpustakaan di ambil menggunkan append dan kemudian duplicut (diperbanyak).
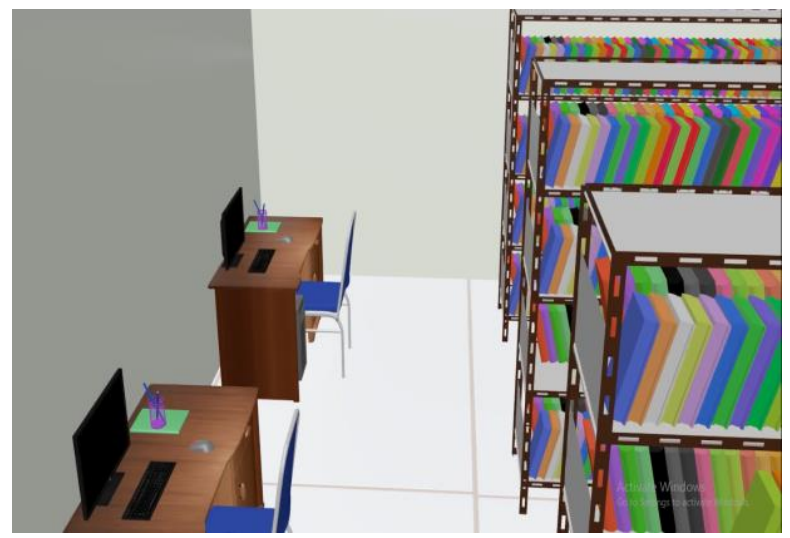

Gambar 16. Scene ketigabelas

Pada scene kesembilanbelas gambar 17 disini memperlihatkan halaman belakang gedung Fakultas Teknik dilantai dua, laboratorium dasar dan laboratorium jaringan.

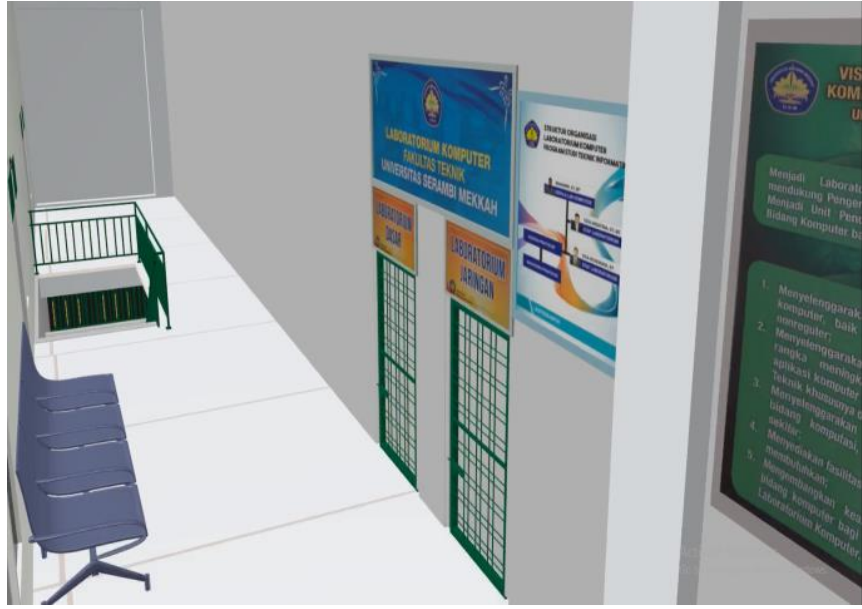

Gambar 17. Scene kesembilanbelas

Disini juga terdapat kursi umum yang diambil melalui proses append. Untuk poster yang ada didepan pintu lab ditambahkan tekstur sedikit agar dapat diletakkan dianimasi $3 \mathrm{D}$ ini.

Pada scene keduapuluh gambar 18 memperlihatkan ruangan dalam lab yang mana terdapat beberapa computer yang dapat dioperasikan oleh mahasiswa.

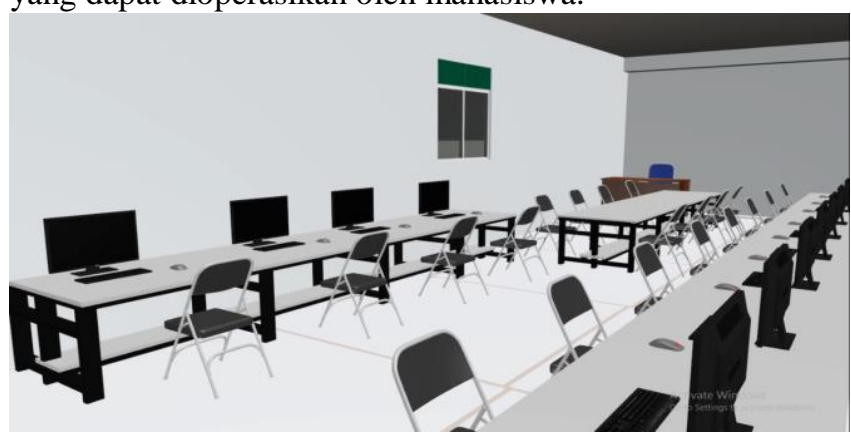

Gambar 18. Scene keduapuluh

Untuk property yang ada diruang di ambil melalui proses append kemudian diduplicut sesuai yang dibutuhkan. Kemudian meja lab dibuat menggunakan object cube dan diberi warna pada menu material.

Pada scene kedua puluh empat gambar 19 menampilkan ruangan kelas belajar mengajar fakultas teknik dan seluruh property.

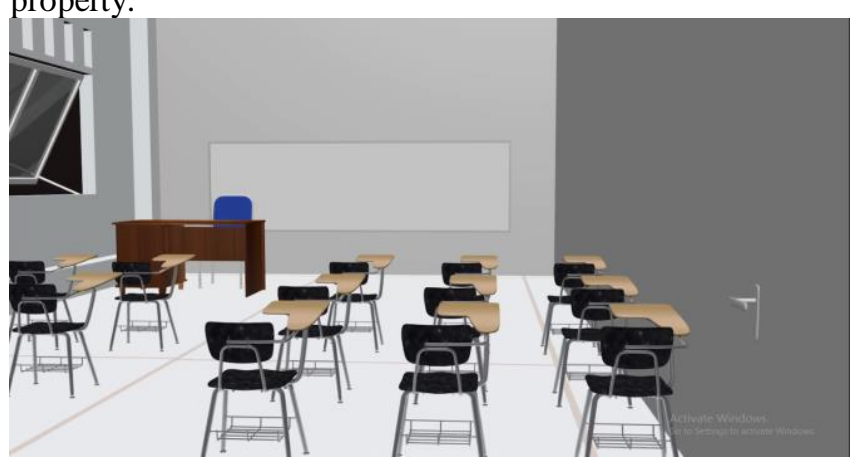

Gambar 19. Scene keduapuluh empat 
Pada property kursi, meja dan papan tulis diambil melalui append dan diduplicut (perbanyak), lalu susun posisi sesuai yang diinginkan. Untuk dinding kelas dibuat menggunakan wall dengan cara klik menu add > mesh > archipack > wall.

\section{Uji Kelayakan}

Untuk mengetahui apakah pembuatan animasi profil prodi dilingkungan Fakultas Teknik Universitas Serambi Mekkah ini berhasil dan layak digunakan sebagai media informasi, maka dilakukan uji kuesioner terhadap 20 responden.

Kuesioner merupakan cara pengumpulan data yang berupa sejumlah pertanyaan tertulis yang harus dijawab secara tertulis oleh responden.

Berikut adalah salah satu pertanyaannya: Apakah menurut anda media animasi ini dapat memberikan informasi kepada masyarakat tentang profil prodi di lingkungan Fakultas Teknik Universitas Serambi Mekkah?

Penyelesain :

$$
\begin{array}{ll}
\text { - Setuju } \quad \mathrm{P}=\frac{14}{20} \times 100 \% \\
\mathrm{P}=70 \% \\
\text { - } \text { Kurang Setuju : } \quad \mathrm{P}=\frac{6}{20} \times 100 \% \\
\mathrm{P}=30 \% \\
\text { Tidak Setuju : } \\
\mathrm{P}=\frac{0}{20} \times 100 \% \\
\mathrm{P}=0 \%
\end{array}
$$

Dari 20 responden, terdapat jawaban setuju sebanyak 14 orang berarti $70 \%$, jawaban kurang setuju sebanyak 6 orang berarti $30 \%$ sedangkan orang yang menjawab tidak setuju tidak ada atau 0 berarti $0 \%$.

Melihat dari hasil diatas dapat diketahui bahwa sebagian besar responden menyatakan setuju lebih banyak, nilai ratarata persentase jawaban setuju bila dijumlahkan memiliki jumlah total 425 , untuk melihat rata-rata hasil kuesioner yaitu presentase jawaban setuju dibagi dengan jumlah pertanyaan, sehingga memperoleh rata-rata hasil 85\%, maka dari itu pembuatan profil prodi di lingkungan Fakultas Teknik Universitas Serambi Mekkah berbasis animasi 3D ini layak untuk digunakan sebagai media informasi.

\section{Kesimpulan Dan Saran}

Berdasarkan hasil penelitian ini, maka dapat disimpulkan bahwa penelitian ini telah menghasilkan sebuah media Animasi 3D tentang profil Program Studi di Fakultas Teknik Universitas Serambi Mekkah yang dapat digunakan sebagai media informasi dan promosi untuk menarik minat masyarakat khususnya calon mahasiswa baru. Berdasarkan hasil uji kelayakan menggunakan kuisioner maka dapat dinyatakan kelayakan terhadap Animasi 3D yang telah dihasilkan dengan persentase yaitu $85 \%$.

\section{Daftar Pustaka}

[1]. Aditya. 2009. Trik Dahsyat Menjadi Animator 3D Handal. Penerbit Andi. Yogyakarta

[2]. Albardon. 2010. Definisi Animasi. Jakarta : PT. Raja Grafindo

[3]. Damar Pradiptojati. 2014. Rancang Bangun Peta Virtual 3D Jurusan Teknik Informatika Institut Teknologi Sepuluh Nopember dengan Unity3D Engine. JURNAL TEKNIK POMITS Vol. 3, No. 2, ISSN: 2337-3539.

[4]. Ervina Meyra Nocia. 2017. Perancangan Media Informasi Gedung Bersejarah Di Kota Surabaya Jurnal Tugas Akhir Universitas Telkom. e-Proceeding of Art \& Design : Vol.4, No.3, ISSN : 2355-9349.

[5]. Kresno Murti Mulyono. 2012. Pembuatan Game Labirin Dengan Menggunakanblender 3d. Jurnal DASI. Vol. 13 No. 2, ISSN: 1411-3201.

[6]. Marfil Vialli Rompas. 2016. Perancangan Gedung Fakultas Teknik Unsrat Dengan Perspektif Animasi 3D. Program Studi Teknik Informatika, Fakultas Teknik, Universitas Sam Ratulangi.

[7]. Munir. 2009. Multimedia Konsep dan Aplikasi dalam Pendidikan. Bandung: CV Afabeta

[8] Zulfan and Samsuddin, "Analisa \& Perancangan Edukasi Keamanan Berlalu Lintas bagi Masyarakat Berbasis Konten Multimedia Animasi," Anal. Peranc. Edukasi Keamanan Berlalu Lintas bagi Masy. Berbas. Konten Multimed. Animasi, vol. 1, no. 1, pp. 22-30, 2016.

[9] Z. Zulfan, D. Satria, and F. Akbar, "Perancangan Permainan Rescue-Heli Online Berbasis Macromedia Flas," J. Nas. Komputasi Dan Teknol. Inf., vol. 1, no. 1, 2018.

[10] Z. Zulfan and B. Baihaqi, "Pemanfaatan Konten Multimedia Animasi Dua Dimensi sebagai Media Pelestarian Alat Musik Etnik Aceh," J. Nas. Komputasi dan Teknol. Inf., vol. 1, no. 2, 2018. 